\title{
AN EPIDEMIOLOGICAL STUDY OF HYPERTENSION AND DIABETES WITH SPECIAL REFERENCE TO ALCOHOL AND TOBACCO ADDICTION AND TREATMENT COMPLIANCE IN ABOVE 40 YEARS AGE GROUP IN A SLUM AREA OF CHENNAI
}

\author{
Dr. S. H. Ali
}

\section{Dr Ali. S. H, Assistant Professor, Community Medicine, Rajamuthiah Medical College, Chidambaram}

\section{CORRESPONDING AUTHOR-}

Dr Syed Hubbe Ali,

Rajah Muthiyah Medical College campus,

Chidambaram.

Email-drsyed_ali@rediffmail.com

\begin{abstract}
:
Context: India is in a stage of epidemiological transition, facing a dual burden of communicable and non- communicable diseases; and as in developed countries the non-communicable diseases in India are assuming a more menacing proportion. A recent Chennai Corporation survey found that at least one in five people in Chennai's slums had hypertension and more than one in ten had diabetes. Aims: To assess the prevalence of hypertension and diabetes in above 40 years age group in a slum area of Chennai and to study the association of these diseases with addiction to alcohol and tobacco. The study also focuses on compliance of patients to treatment for hypertension and diabetes. Settings and Design: Urban slum in Chennai, Cross sectional study. Materials and Methods: Present study was undertaken in a slum in Chennai in persons above 40 years age group. One slum was selected randomly and the households in the slum were sampled by a systematic random sampling method. A pre-designed and pre-tested questionnaire was used to collect information regarding the socio-demographic profile, past history of hypertension and diabetes, history of addiction to alcohol and tobacco (smoking or chewing) and compliance to treatment for known hypertensive's and diabetics. Statistical analysis: The prevalence was expressed in percentage and the Chi square test was used to find association with the factors. Results: The prevalence of Hypertension was $39.17 \%$ and Diabetes was $15.49 \%$. The overall prevalence of addiction to alcohol, smoking and/or tobacco among study population in males was $74.86 \%$ and females $50.23 \%$. In male study population the prevalence of addiction among hypertensive's and diabetics was $93.54 \%$ $(\mathrm{p}<0.001)$ and $96.77 \%(\mathrm{p}<0.001)$ respectively. In female study population the prevalence of addiction among hypertensive's and diabetics was $62.02 \%(\mathrm{p}<0.005)$ and $37.28 \%(\mathrm{p}<0.05)$ respectively. Compliance to treatment was more in females as compared to males. Conclusion: There is a rising prevalence of hypertension and diabetes among the urban slum dwellers. Addiction to alcohol and/or tobacco was found to be an important factor contributing to the
\end{abstract}

Journal of Evolution of Medical and Dental Sciences/ Volume 1/ Issue 1/ Jan- March 2012 


\section{ORIGINAL ARTICLE}

causation of hypertension and diabetes. Compliance to treatment was poor among males as compared to females.

Key Words: Hypertension, Diabetes, Addiction, Treatment Compliance.

\section{INTRODUCTION:}

WHO Inter- Health research project has shown that non- communicable disease prevalence rate in developing countries was similar to that in advanced nations 30 years ago. The emergence of this non- communicable disease cluster "The New- World Syndrome" appears to be a result of socio- economic and demographic changes (WHO 1994). The non communicable diseases, which contributed to $29 \%$ of DALY loss in 1990, are projected to rise to $57 \%$ by AD 2020 (1). Hypertension and Diabetes are becoming an important public health problem worldwide. A recent report on the Global burden of hypertension indicates that nearly 1 billion adults (more than a quarter of the world's population) had hypertension in 2000, and this is predicted to increase to 1.56 billion by 2025 (2). The World Health Organization and the International Diabetes Federation, among others, have already warned that more than half of new diabetics will be from disadvantaged communities as many of them will not be able to afford cost of treatment.(3). India is in a stage of epidemiological transition, facing a dual burden of communicable and noncommunicable diseases; and as in developed countries the non- communicable diseases in India are assuming a more menacing proportion (1). Population-based surveys conducted in limited areas to study risk factors for various diseases and mortality has reported information on tobacco use (4). Alcohol abuse, cigarette smoking and other forms of tobacco use are key risk factors for noncommunicable diseases like hypertension and diabetes (5). Since, there are not many studies on significance of addiction on hypertension and diabetes in India, the present study was under taken on epidemiology of hypertension and diabetes with reference to alcohol and tobacco addiction. Also compliance of patients towards treatment of hypertension and diabetes were studied.

\section{MATERIALS AND METHODS:}

The present study was a community based, cross sectional study carried out in an urban slum in Chennai among persons aged 40 years and above from December 2011- March 2012. Ethical clearance was obtained. From 10 zones of Chennai, zone five was randomly chosen by a lottery method. There were 66 slums in zone five, from among which one slum was randomly chosen by a lottery method. The selected slum has a population of 11,041 . The total number of households was 2122 (source- updated family register of the selected slum). All 2122 houses were surveyed using complete enumeration technique. House to house approach was used for the initial enumeration. During the survey a total of 2650 persons above the age of 40 years were found to be residing in this slum. Out of these, 30\% i.e. 794 subjects were included for the study and

Journal of Evolution of Medical and Dental Sciences/ Volume 1/ Issue 1/ Jan- March 2012 
interviewed by using a pretested, formatted, close ended proforma. The first house was selected by random sampling technique. All persons in this household in above 40 years age group were interviewed. The next house was selected by systematic sampling technique by taking every $\mathrm{K}^{\text {th }}$ house by below formula

$\mathrm{K}=\frac{\text { Total population above } 40 \text { year }}{\text { Sample size desired }}=\underline{2650}=\underline{30 \% \text { of total }} \quad \begin{aligned} & 30 \% \text { of } 2650 \\ & 3050\end{aligned}=\underline{2650}=3.33$

Thus every third house was selected for the study and all persons above 40 years in a particular house were interviewed till a total of 794 persons were interviewed. Information regarding socio- demographic profile was questioned. The persons were also enquired about the known history of hypertension and diabetes. Also addiction to alcohol and tobacco was enquired. Use of tobacco in any form such as smoking beedi or cigarette and chewing tobacco with betel quid (paan), with or without lime paste, with or without supari, or in the form of gutkha (mawa) was enquired. The duration of addiction was categorized as less than 5 years, 5 to 15 years and more than 15 years. The blood pressure of every individual was checked with a mercury column sphygmomanometer. The blood glucose level of study subject was measured using a glucometer and a random capillary blood was used for measuring blood glucose.

Hypertension was classified as per "Association of Physicians of India"(6). Diabetes was classified as per "Diagnostic values for oral GTT and Clinical classification of Diabetes Mellitus"(7).

\section{RESULTS:}

The overall prevalence of hypertension (HTN) in this urban slum was $39.17 \%$ (males $49.45 \%$ and females $30.37 \%$ ). The prevalence of diabetes (DM) was $15.49 \%$ (males $14.48 \%$ and females $16.36 \%$ )

\begin{tabular}{|c|c|c|c|c|c|}
\hline \multirow[t]{2}{*}{ Sex } & \multirow{2}{*}{$\begin{array}{l}\text { Persons with } \\
\text { HTN (n) }\end{array}$} & \multirow{2}{*}{$\begin{array}{l}\text { Persons with } \\
\text { DM (o) }\end{array}$} & \multirow{2}{*}{$\begin{array}{l}\text { Study } \\
\text { Population (p) }\end{array}$} & \multicolumn{2}{|c|}{ Prevalence Rate \% } \\
\hline & & & & $\begin{array}{l}\text { HTN } \\
n / p \times 100\end{array}$ & $\begin{array}{l}\mathrm{DM} \\
\mathrm{o} / \mathrm{p} \times 100\end{array}$ \\
\hline Males & 181 & 53 & 366 & 49.45 & 14.48 \\
\hline Females & 130 & 70 & 428 & 30.37 & 16.36 \\
\hline Total & 311 & 123 & 794 & 39.17 & 15.49 \\
\hline
\end{tabular}

Table 1: Prevalence of Hypertension and Diabetes in study population 
Majority of male study subjects were addicted to smoking, alcohol and tobacco and females were addicted to tobacco chewing. Among males 274 (74.86\%) and females 215 (50.23\%) were addicted to some form of addiction to alcohol, smoking or tobacco chewing.

\begin{tabular}{|ll|l|l|l|l|}
\hline \multirow{2}{*}{ Addiction } & \multicolumn{2}{|l|}{ Males } & Females \\
\cline { 2 - 5 } & $\mathrm{N}$ & Percent \% & $\mathrm{N}$ & Percent \% \\
\hline $\begin{array}{l}\text { Smoking } \\
\text { Alcohol } \\
\text { Tobacco }\end{array}$ & 105 & 28.69 & 26 & 6.07 \\
\hline $\begin{array}{l}\text { Smoking } \\
\text { Alcohol }\end{array}$ & & & & \\
\hline $\begin{array}{l}\text { Alcohol } \\
\text { Tobacco }\end{array}$ & 42 & 11.48 & 0 & 0 \\
\hline $\begin{array}{l}\text { Smoking } \\
\text { Tobacco }\end{array}$ & 24 & 6.56 & 9 & 2.10 \\
\hline Smoking & 18 & 4.92 & 17 & 3.97 \\
\hline Tobacco & 34 & 9.29 & 0 & 0 \\
\hline Alcohol & 22 & 6.01 & 163 & 38.08 \\
\hline NIL & 29 & 7.92 & 0 & 0 \\
\hline Total & 92 & 25.14 & 213 & 49.77 \\
\hline
\end{tabular}

Table 2: Distribution of addiction among study population.

With reference to duration of addiction, $64.25 \%$ were addicted for more than past 15 years.

\begin{tabular}{|c|c|c|c|c|c|c|c|c|c|c|c|c|c|c|c|c|}
\hline $\begin{array}{l}\text { Durati } \\
\text { on of } \\
\text { addict } \\
\text { ion }\end{array}$ & \multicolumn{2}{|c|}{$\begin{array}{l}\text { Smoking + } \\
\text { Alcohol + } \\
\text { Tobacco }\end{array}$} & \multicolumn{2}{|c|}{$\begin{array}{l}\text { Smoking } \\
+ \\
\text { Alcohol }\end{array}$} & \multicolumn{2}{|c|}{$\begin{array}{l}\text { Alcohol } \\
+ \\
\text { Tobacc } \\
\text { o }\end{array}$} & \multicolumn{2}{|c|}{$\begin{array}{l}\text { Smoking } \\
+ \\
\text { Tobacco }\end{array}$} & \multicolumn{2}{|c|}{ Smoking } & \multicolumn{2}{|c|}{ Tobacco } & \multicolumn{2}{|c|}{ Alcohol } & \multicolumn{2}{|c|}{ Total } \\
\hline years & $\mathrm{N}$ & $\%$ & $\mathrm{~N}$ & $\%$ & $\mathrm{~N}$ & $\%$ & $\mathrm{~N}$ & $\%$ & $\mathrm{~N}$ & $\%$ & $\mathrm{~N}$ & $\%$ & $\mathrm{~N}$ & $\%$ & $\mathrm{~N}$ & $\%$ \\
\hline$<5$ & 16 & 12.0 & 0 & 0 & 0 & 0 & 5 & $\begin{array}{l}15.3 \\
8\end{array}$ & 0 & 0 & 1 & 0.78 & 0 & 0 & 22 & 5.78 \\
\hline $5-15$ & 29 & $\begin{array}{l}22.1 \\
4\end{array}$ & $\begin{array}{l}1 \\
0\end{array}$ & $\begin{array}{l}23.8 \\
1 \\
\end{array}$ & 0 & 0 & 7 & $\begin{array}{l}19.2 \\
3\end{array}$ & $\begin{array}{l}1 \\
1\end{array}$ & $\begin{array}{l}33.3 \\
3 \\
\end{array}$ & 3 & $\begin{array}{l}15.2 \\
6\end{array}$ & 0 & 0 & $\begin{array}{l}11 \\
4\end{array}$ & $\begin{array}{l}29.9 \\
7\end{array}$ \\
\hline$>15$ & 86 & $\begin{array}{l}65.9 \\
2\end{array}$ & $\begin{array}{l}3 \\
2\end{array}$ & $\begin{array}{l}76.1 \\
9\end{array}$ & $\begin{array}{l}3 \\
3\end{array}$ & $\begin{array}{l}10 \\
0\end{array}$ & $\begin{array}{l}2 \\
3\end{array}$ & $\begin{array}{l}65.3 \\
8\end{array}$ & $\begin{array}{l}2 \\
3\end{array}$ & $\begin{array}{l}66.6 \\
7\end{array}$ & 18 & $\begin{array}{l}83.9 \\
6\end{array}$ & 29 & $\begin{array}{l}10 \\
0\end{array}$ & $\begin{array}{l}24 \\
4\end{array}$ & $\begin{array}{l}64.2 \\
5\end{array}$ \\
\hline Total & $\begin{array}{l}13 \\
1\end{array}$ & 100 & $\begin{array}{l}4 \\
2\end{array}$ & 100 & $\begin{array}{l}3 \\
3\end{array}$ & $\begin{array}{l}10 \\
0\end{array}$ & $\begin{array}{l}3 \\
5\end{array}$ & 100 & $\begin{array}{l}3 \\
4\end{array}$ & 100 & 22 & 100 & 29 & $\begin{array}{l}10 \\
0\end{array}$ & $\begin{array}{l}38 \\
0\end{array}$ & 100 \\
\hline
\end{tabular}

Table 3: Duration of addiction among study population. 
Among hypertensive's $93.54 \%$ males and $62.02 \%$ females were having some form of addiction to tobacco and/or alcohol in any form.

\begin{tabular}{|l|l|l|l|l|l|l|}
\hline & \multicolumn{4}{l|}{ Hypertension } & \multicolumn{4}{l|}{ No Hypertension } & Total \\
\hline & $\mathrm{N}$ & $\%$ & $\mathrm{~N}$ & $\%$ & $\mathrm{~N}$ & $\%$ \\
\hline Addicts & 169 & 93.54 & 105 & 56.59 & 274 & 74.86 \\
\hline Non Addicts & 12 & 6.46 & 80 & 43.41 & 92 & 25.14 \\
\hline Total & 181 & 100 & 185 & 100 & 366 & 100 \\
\hline
\end{tabular}

Chi square= 65.17 at $\mathrm{P}<0.001$ @d.f.=1. (Table value=10.83)

\begin{tabular}{|l|l|l|l|l|l|l|}
\hline & \multicolumn{2}{|l|}{ Hypertension } & \multicolumn{2}{l|}{ No Hypertension } & \multicolumn{2}{l|}{ Total } \\
\hline & $\mathrm{N}$ & $\%$ & $\mathrm{~N}$ & $\%$ & $\mathrm{~N}$ & $\%$ \\
\hline Addicts & 81 & 62.02 & 134 & 45.09 & 215 & 50.23 \\
\hline Non Addicts & 49 & 37.98 & 164 & 54.91 & 213 & 49.77 \\
\hline Total & 130 & 100 & 298 & 100 & 428 & 100 \\
\hline
\end{tabular}

Table 5: Relationship between addiction and hypertension in Females. Chi square= 10.89 at $\mathrm{P}<0.005$ @d.f.=1. (Table value=7.88)

Among diabetics $96.77 \%$ males and $37.28 \%$ females were having some form of addiction to tobacco and/or alcohol in any form.

\begin{tabular}{|l|l|l|l|l|l|l|}
\hline & \multicolumn{4}{|l|}{ Diabetes } & No Diabetes & Total \\
\hline & $\mathrm{N}$ & $\%$ & $\mathrm{~N}$ & $\%$ & $\mathrm{~N}$ & $\%$ \\
\hline Addicts & 51 & 96.77 & 223 & 71.15 & 274 & 74.86 \\
\hline Non Addicts & 2 & 3.23 & 90 & 28.85 & 92 & 25.14 \\
\hline Total & 53 & 100 & 313 & 100 & 366 & 100 \\
\hline
\end{tabular}

Chi square= 15.03 at $\mathrm{P}<0.001$ @d.f.=1. (Table value=10.83)

\begin{tabular}{|l|l|l|l|l|l|l|}
\hline & \multicolumn{3}{|l|}{ Diabetes } & No Diabetes & Total \\
\hline & $\mathrm{N}$ & $\%$ & $\mathrm{~N}$ & $\%$ & $\mathrm{~N}$ & $\%$ \\
\hline Addicts & 26 & 37.28 & 189 & 52.77 & 215 & 50.23 \\
\hline Non Addicts & 44 & 62.72 & 169 & 47.23 & 213 & 49.77 \\
\hline Total & 70 & 100 & 358 & 100 & 428 & 100 \\
\hline
\end{tabular}

Table 7: Relationship between addiction and diabetes in Females. Chi square= 5.74 at $\mathrm{P}<0.05$ @d.f.=1. (Table value=3.84) 


\section{ORIGINAL ARTICLE}

92\% females and 80\% males having both Diabetes and Hypertension were taking treatment regularly. Defaulter rate was higher in male diabetics i.e. $42.86 \%$

\begin{tabular}{|l|l|l|l|l|l|l|}
\hline Disease & Sex & Total Cases & Regular Treatment & \multicolumn{2}{l|}{ Irregular Treatment } \\
\hline & & & N & $\%$ & N & $\%$ \\
\hline \multirow{3}{*}{ Hypertension } & Male & 141 & 87 & 61.53 & 54 & 38.47 \\
\cline { 2 - 7 } & Female & 88 & 57 & 64.28 & 31 & 35.72 \\
\hline \multirow{2}{*}{ Diabetes } & Male & 27 & 15 & 57.14 & 12 & 42.86 \\
\cline { 2 - 7 } & Female & 40 & 26 & 66.00 & 14 & 34.00 \\
\hline $\begin{array}{l}\text { Hypertension } \\
+ \text { Diabetes }\end{array}$ & Male & 66 & 53 & 80.00 & 13 & 20.00 \\
\cline { 2 - 7 } & Female & 72 & 66 & 92.00 & 6 & 8.00 \\
\hline
\end{tabular}

Table 8: Compliance to Treatment

\section{DISCUSSION:}

The study was carried out in an urban slum of Chennai, to find out the prevalence of hypertension and diabetes and its association with addiction to alcohol and tobacco (smoking and chewing) in above 40 years age group. The prevalence of hypertension in the study subjects was found to be $39.17 \%$ (males $49.45 \%$ and females $30.37 \%$ ). A similar study conducted in Chennai (CURES-52) in 2007, showed the prevalence of hypertension as $20 \%$ (males $23.2 \%$ and females $17.1 \% \mathrm{P}<0.001$ ) (8). Blood pressure rises with age in both sexes and the rise is greater in those with higher initial blood pressure (9). A study conducted in the urban areas of Chennai during 2000 (age group $>=40)$ reported a higher prevalence of hypertension (54\%) among low income group (monthly income < Rs 30000/annum and 40\% prevalence among high-income group (monthly income $\geq$ Rs 60000/annum) (10). Hypertension is more common in men as compared to women up to 50 years after which the percentage of females with hypertension increases as compared to males (11) The prevalence of diabetes in the study subjects was found to be $15.49 \%$ (males $14.48 \%$ and females 16.36\%). Another study conducted in Chennai showed the prevalence of diabetes in urban and rural Chennai as $13.5 \%$ and $6.9 \%$ respectively (12). Studies from urban Chennai reported the prevalence of diabetes at $11.6 \%$ in the year 1995 and 14\% during 2000 (10). 74.86\% males and $50.23 \%$ females were having some sort of addiction to alcohol, smoking or tobacco chewing or a combination of these among study population. Among males $28.69 \%$ were addicted to alcohol, smoking and tobacco chewing and among females $38.08 \%$ were addicted to tobacco chewing. Studies done in Tamil Nadu have shown that the prevalence of tobacco smoking among middle aged (35-69 yrs) men is 38\% in urban area and 47\% in rural area and among females less than $1 \%$ irrespective of their area of residence(13). $64.5 \%$ addicts were in habit of addiction for more than past 15 years. Tobacco use increases with increasing age.(13). Among hypertensive's 93.54\% males and $62.02 \%$ females were having some form of addiction to tobacco and/or alcohol

Journal of Evolution of Medical and Dental Sciences/ Volume 1/ Issue 1/ Jan- March 2012 
in any form. It is well established fact that tobacco smoking is a cause for rise in blood pressure. Nicotine in tobacco causes increased secretion of catecholamine's causing rise in blood pressure (14). Among diabetics $96.77 \%$ males and $37.28 \%$ females were having some form of addiction to tobacco and/or alcohol in any form. Extensive intake of alcohol can cause increased risk of diabetes by damaging pancreas and liver and by promoting obesity (15). 92\% females and 80\% males having both Diabetes and Hypertension were taking treatment regularly. Defaulter rate was higher in male diabetics i.e. $42.86 \%$. This was probably due to silent nature of disease and lack of knowledge and awareness about regular treatment and hazards of irregular treatment. Regular treatment is defined as attending $75 \%$ of scheduled visits to health facility (49).

\section{REFERENCES:}

1. Epidemiology of Non communicable diseases. Essential preventive medicine, O.P. Ghai and Piyush Gupta $1^{\text {St }}$ edition (1999). Pg. no. 1589-90.

2. Kearney PM, Whelton M, Reynolds K, Muntner P, Whelton PK, He J. Global burden of hypertension: analysis of worldwide data.Lancet 2005;365:217-23.

3. http://timesofindia.indiatimes.com/topic/World-Health-Organisation 2012.

4. Tobacco use in India: Practices, patterns and prevalence. Tobacco Free Initiative 03. Chapter 3.2 .

5. Livtak J. et. al. (1987) Bulletin PAHO, vol. 21.pg. 2.

6. Text book of Medicine; Association of Physicians of India. $6^{\text {th }}$ edition 1999. Pg 208, 401-04.

7. Park's text Book of Preventive and Social Medicine, 19 th edition Pg. 327

8. Prevalence, Awareness and Control of Hypertension in Chennai - The Chennai Urban Rural Epidemiology Study (CURES - 52). JAPI. Vol 55. May 2007

9. Harrison's principles of Internal Medicine vol. 2. 16 ${ }^{\text {th }}$ edition (2005) Pg. 1463

10. National Cardio vascular disease database. MOHFW and WHO.IC Health. SE/04/233208

11. Text book of Medicine; Association of Physicians of India. $6^{\text {th }}$ edition 1999. Pg 208, 401-04.

12. Study by Madras Diabetes Research Foundation, 14 Dec 2010.

13. Tobacco survey among youth in Tamil Nadu. Epidemiological Research Centre, Chennai India.2000.

14. National Health Programmes of India, J. Kishore. $5^{\text {th }}$ edition 2005 pg.245,247

15. World Health organization (1980) technical Report Series No. 727 pg 18.

16. WHO (1980). Guide to Leprosy control. WHO Geneva Pg. 27-28. 